\title{
THE EFFECT OF ACHENE HETEROMORPHISM ON GERMINATION IN THE SHAGGY SOLDIER [Galinsoga ciliata (RAFIN) S.F. BLAKE]
}

\author{
Magdalena Kucewicz, Aneta Wardzyńska, Anna Źróbek-Sokolnik
}

University of Warmia and Mazury, Department of Botany and Nature Protection, Plac Łódzki 1, 10-718 Olsztyn, Poland e-mail: magdo@moskit.uwm.edu.pl

Received: 30.08 .2010

\begin{abstract}
Heteromorphic achenes are formed within each capitulum of Galinsoga ciliata (Rafin) S.F. Blake. We examined (1) the effects of the duration of dry storage on germination and (2) the effect of burial in soil on viability and germination of heteromorphic diaspores. Fresh harvested peripheral achenes remained dormant, while central achenes germinated at $60 \%$. Both achene types became non-dormant after one month of dry storage. In successive months of dry storage, peripheral achenes demonstrated a higher germination percentage than central achenes. The peripheral and central achenes showed similar temperature requirements during dry storage. A similar germination pattern was observed in both achene types, with a germination peak in March (96\% of peripheral achenes at 12, 26 and $34^{\circ} \mathrm{C}$; $90 \%$ of central achenes at 26 and $34^{\circ} \mathrm{C}$ ). The germination capacity deteriorated over time. After 19 months of dry storage, both achene morphs failed to germinate at $12^{\circ} \mathrm{C}$. At a $26^{\circ}$ and $34^{\circ} \mathrm{C}$, the same group of achenes continued to germinate at a relatively high level. After six and seven months of soil storage, $90-95 \%$ of both achene types remained alive. Dimorphic achenes were characterized by similar germination percentage $(89-99 \%)$ at all temperature intervals, whereas peripheral achenes exhumed in May were the fastest to germinate. After 18 months of storage in soil (successive growing season), most of the harvested achenes were dead. The studied achenes did not form a permanent seed bank.
\end{abstract}

Key words: Galinsoga ciliata, heteromorphism, germination, dry storage, soil seed bank

\section{INTRODUCTION}

The shaggy soldier [Galinsoga ciliata (Rafin) S.F. Blake, family Asteraceae], a popular root crop weed, is a neophyte species introduced to Poland around 80 years ago. A native of South America, Mexico and Chile, the shaggy soldier was described as a rare species in Poland in 1929 (M a j d e c k a-Z Z zi ar s ka,
1929). Today, it is believed to be a widely propagating and increasingly aggressive species (K o r n i a k, 1997). The shaggy soldier is an invasive alien species which contributes to the uniformity of the native flora (www.iop.krakow.pl/ias/2010). This annual plant produces heteromorphic achenes within each capitulum.

Seed heteromorphism and fruit heterocarpy (the production of different types of seeds or fruits by an individual plant, respectively; in the present study, the term seed heteromorphism is used in its broad sense, including fruit heterocarpy that has evolved independently in distinct taxonomic groups. Seed heteromorphism has been documented in 18 families of angiosperms of which the main is Asteraceae (63\% of the recorded species, $52 \%$ of the genera). (B a s k in and B a s k i n, 1998; I m bert, 2002). Differentiation among seed morphs has been found to be more common in desert annuals or ruderal weeds that exist in highly variable and unpredictable habitats (E11ne r and Sh mida, 1984; H a r per, 1977; V en able, 1985; V e nable and Lawlor, 1980).

In most Asteraceae, the morphological differentiation between achenes (one-seeded fruits) is related to the position in the capitulum. Peripheral achenes are formed from ray florets in the outer whorl, while central achenes develop from disc florets situated above. The morphological heteromorphism results in different ecological strategies (ecological consequences), including dispersal capacity, dormancy and germination requirements, seedling emergence, seedling growth, and survival or fecundity (i.a. B a s k i n and B askin, 1998; Chmielewski, 1999; Corkidi et al. 1991; El-Keblawy, 2002; Imbert, 2002; Matilla et al. 2005; R ocha, 1996; Ve$\mathrm{nable}$ et al. 1995), which have evolutionary significance (Chmielewski, 1999). Plants produce seeds with varied dispersal, dormancy and germination 
requirements to survive in unsupportive habitats. This evolutionary mechanism has been developed to prevent species extinction under adverse and variable environmental conditions (S y m on i d e s, 1989).

Among many studies that have examined germination, dormancy and dispersal capacity, few studies examine the effect of short-term and long-term dry storage on germination and dormancy breaking in species of Asteraceae that produce heteromorphic achenes (I m b e r t, 1999; R o c h a, 1996). The behavior of dimorphic propagules in the soil seed bank has also been poorly investigated ( $\mathrm{E} \mathrm{s}$ p in o s a $-\mathrm{G}$ a r c i a et al. 2003; Venable and Levin, 1985; Venable et al. 1987).

The objective of this study was to analyze selected biological parameters of heteromorphic G. ciliata achenes. The presented experiments investigated (1) the effects of the duration of dry storage on germination and (2) the effect of burial in soil on viability and germination of heteromorphic diaspores.

\section{MATERIALS AND METHODS}

The experimental materials comprised mature achenes of Galinsoga ciliata (Rafin) S.F. Blake collected on 20 September 2004 from a weed population in carrots grown in the Experimental Garden of the University of Warmia and Mazury in Olsztyn, $53^{\circ} 78^{\prime} \mathrm{N}$ latitude and $20^{\circ} 49^{\prime} \mathrm{E}$ longitude. On the next day after harvest, the achenes were divided into two groups based on their position in the inflorescence. Two distinct types of achenes are produced on the same receptacle. One type, formed from central florets, is characterized by a pappus-scales aristate, the other type, formed from peripheral florets, has a strongly reduced pappus (Kulpa, 1988).

\section{Experiment}

Part of achenes were dry-stored in paper bags under laboratory conditions at ambient temperature $\left(20 \pm 2^{\circ} \mathrm{C}\right)$ and $\mathrm{RH}$ (relative humidity) of $35-45 \%$. The first germination test was carried out on the next day after harvest (21 Sept 2004), and successive tests were preformed once a month for eight consecutive months (4 Nov, 2 Dec 2004; 8 Jan, 9 Feb, 10 Mar, 8 Apr, 1 May, 1 Jun 2005) and after 19 months (20 Apr 2005).

The remaining, freshly-matured achenes (three sets of 250 achenes each in five replications) were mixed with sand, placed in synthetic fabric bags, covered with plastic mesh and buried in soil at a depth of 10 $\mathrm{cm}$ on 21 October 2004. The achenes were exhumed after six months (4 May 2005), seven months (1 June 2005) and 18 months (18 April 2006) at optimal field germination dates. After exhumed, live achenes were counted, and they were referred to as firm achenes because soft achenes were mostly empty or decayed (B o u w mee ster and Kars se n, 1993). After six and seven months of storage, the achenes that were firm were subjected to a germination test at the moment of exhumation.

\section{Germination}

Achenes were placed in Petri dishes on two layers of filter paper moistened with $10 \mathrm{ml}$ of distilled water, in incubators, at constant temperature. The newly-harvested seeds were tested at 12,22 and $26^{\circ} \mathrm{C}$, and the remaining tests were conducted at 12, 26 and $34^{\circ} \mathrm{C}$. Before being tested, the stored seeds were surface sterilized for $1 \mathrm{~min}$ in a $3 \% \mathrm{NaOCl}$ solution and were rinsed with sterile water. For each treatment, five replicates of 25 seeds were used. Seeds were considered to be germinated with the emergence of the radicle. The number of germinated seeds was counted every day. The final percentage of germinated seeds was calculated for 20 days following seed sowing. The results are presented as means of the germination percentages obtained in five replicates $\pm \mathrm{SE}$ of the mean.

The following germination parameters were determined in the tests carried out at $26^{\circ} \mathrm{C}$ (after dry storage for 1-8 and 19 months and after burial for 6 and 7 months): $\mathrm{T}$ - time to first observed germinant, $\mathrm{T}_{100}$ - time to maximum germination and GR (germination rate), calculated as the maximum number of germinants/ (days to maximum germination - days to initial germination), as described by $\mathrm{R}$ o se $11 \mathrm{o}$ and Ma y o l (2002).

\section{RESULTS}

\section{Dry storage}

\section{Germination of freshly harvested} achenes (stored for 1 day)

Freshly harvested central achenes of G. ciliata began to germinate on the fourth day. Their germination capacity exceeded $60 \%$ at $26^{\circ} \mathrm{C}$, while no germination or very weak germination was noted at the remaining temperatures. Peripheral achenes remained dormant in the applied temperature range (Figs 1A, 1B).

\section{Germination of achenes stored for 1-8 and 19 months}

Both central and peripheral achenes became nondormant after one month of storage (Fig. 2). Dormancy was broken at each applied temperature, and the highest germination percentage (both morph types) were observed at $12^{\circ} \mathrm{C}$, reaching $96 \%$ in central achenes and $87 \%$ in peripheral achenes (Fig. 2A). The lowest germination (58\%) was noted in respect of central achenes stored at $34^{\circ} \mathrm{C}$ (Fig. 2C). During further dry storage at all analyzed temperatures $\left(12,26,34^{\circ} \mathrm{C}\right)$, the germination of most peripheral achenes was several percent to more 
than $10 \%$ higher in comparison with central achenes. Central achenes were characterized by higher germination only during the $12^{\circ} \mathrm{C}$ test carried out in the course of the first two experimental months (November, December) and the $34^{\circ} \mathrm{C}$ test performed after 19 months. The highest germination percentage was observed in the fifth month of storage (March), in particular as regards peripheral achenes that germinated at $96 \%$ at 12 , 26 and $34^{\circ} \mathrm{C}$, while the percentage of central achenes germinating at $34^{\circ} \mathrm{C}$ reached $89 \%$. After five months of storage, a gradual decrease in the germination capacity of both morphs was noted. In both achene types, germination capacity deteriorated at a temperature of $12^{\circ} \mathrm{C}$. After eight months of storage, peripheral achenes germinated at $33 \%$, and central achenes $-13 \%$. Achenes dry stored for 19 months failed to germinate at $12^{\circ} \mathrm{C}$. Temperatures of $26^{\circ} \mathrm{C}$ and $34^{\circ} \mathrm{C}$ produced a more supportive germination environment. At $26^{\circ} \mathrm{C}$, peripheral and central achenes were characterized by higher ger- mination capacity after 19 months of dry storage than after eight months (June), which reached $72 \%$ and $56 \%$, respectively. The $34^{\circ} \mathrm{C}$ test carried out after 19 months of storage showed that central achenes maintained their germination capacity $(60 \%)$, whereas the germination rates of peripheral achenes decreased to $30 \%$.

In the $26^{\circ} \mathrm{C}$ tests, the germination of most dry stored dimorphic achenes was induced simultaneously. In some cases, the germination of peripheral achenes began one to two days sooner in comparison with central achenes (exceptions: in the second month of storage, the germination of peripheral achenes was induced four days sooner, and in the fourth month, central achenes began to germinate a day before peripheral achenes). The germination period of each morph type varied, lasting from three to 12 days (Fig. 3). In most cases, insignificantly higher GR values were noted for peripheral achenes (Fig. 4).

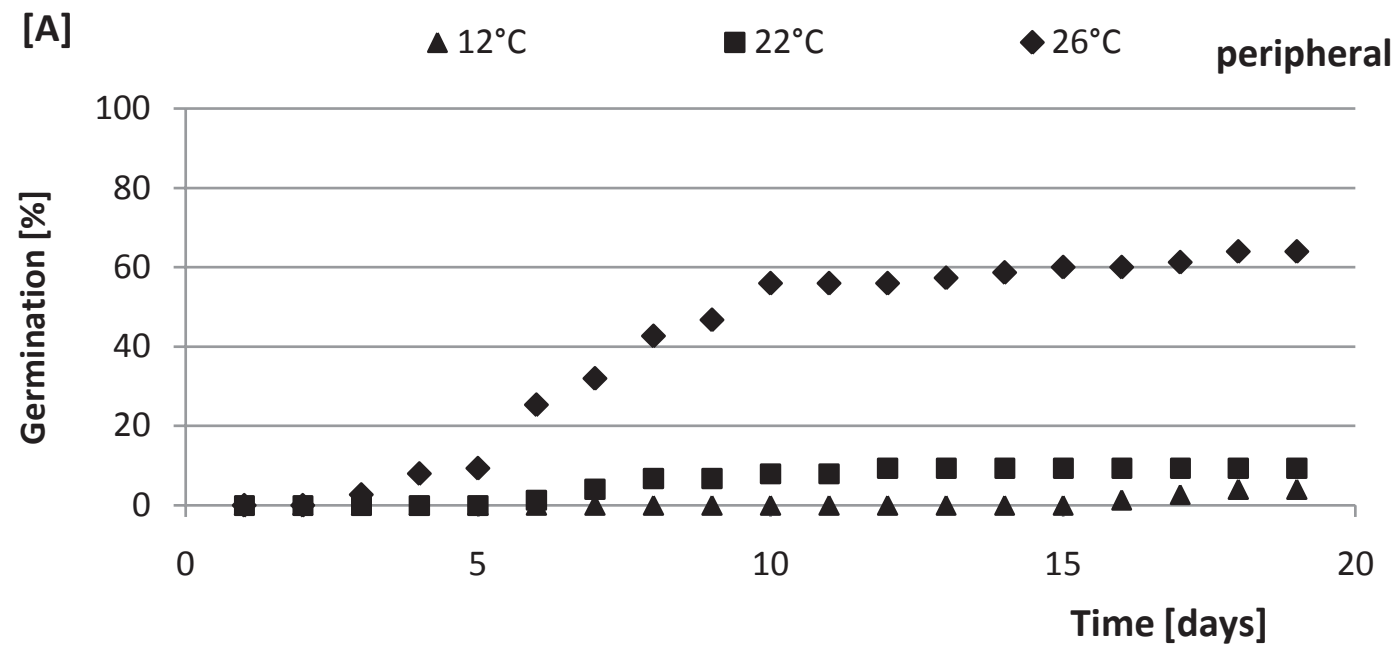

[B]
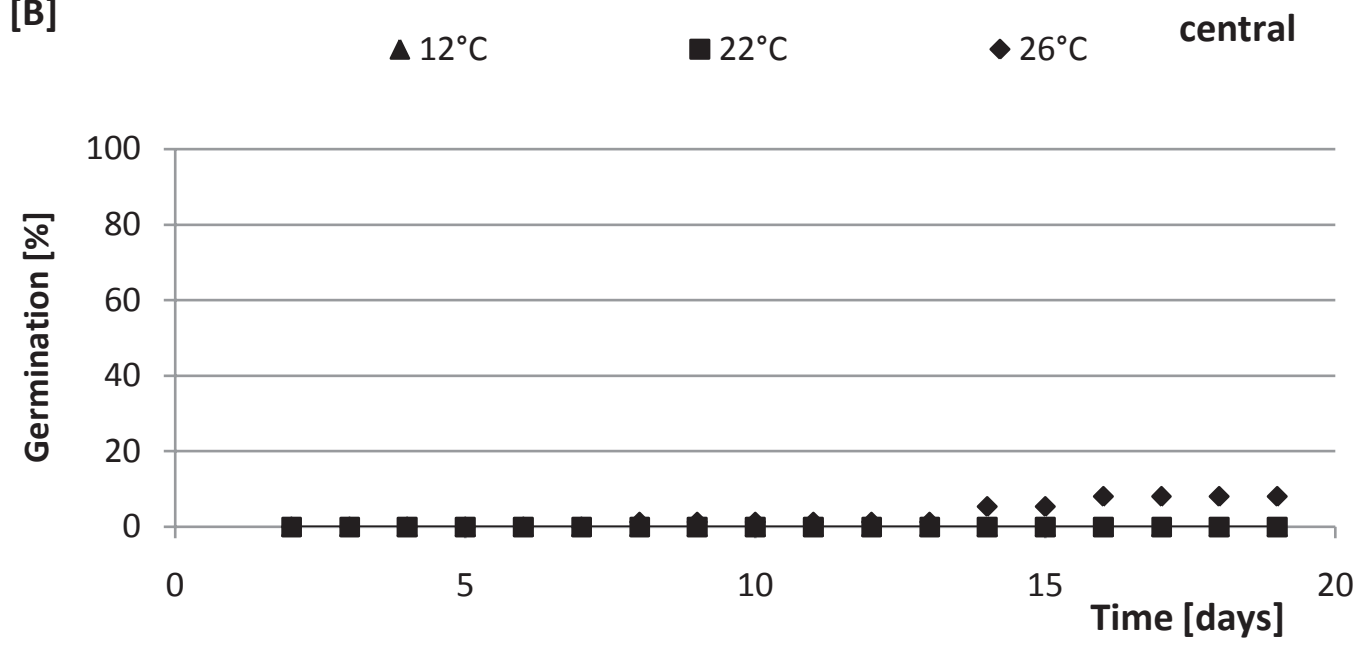

Fig. 1. Cumulative mean percentage of germination of fresh achenes (1 day of dry storage) from peripheral (A) and central (B) positions in the capitulum of Galinsoga ciliata. The achenes were tested at 12,22 and $26^{\circ} \mathrm{C}$. 
[A] $\longrightarrow$ peripheral ----- central

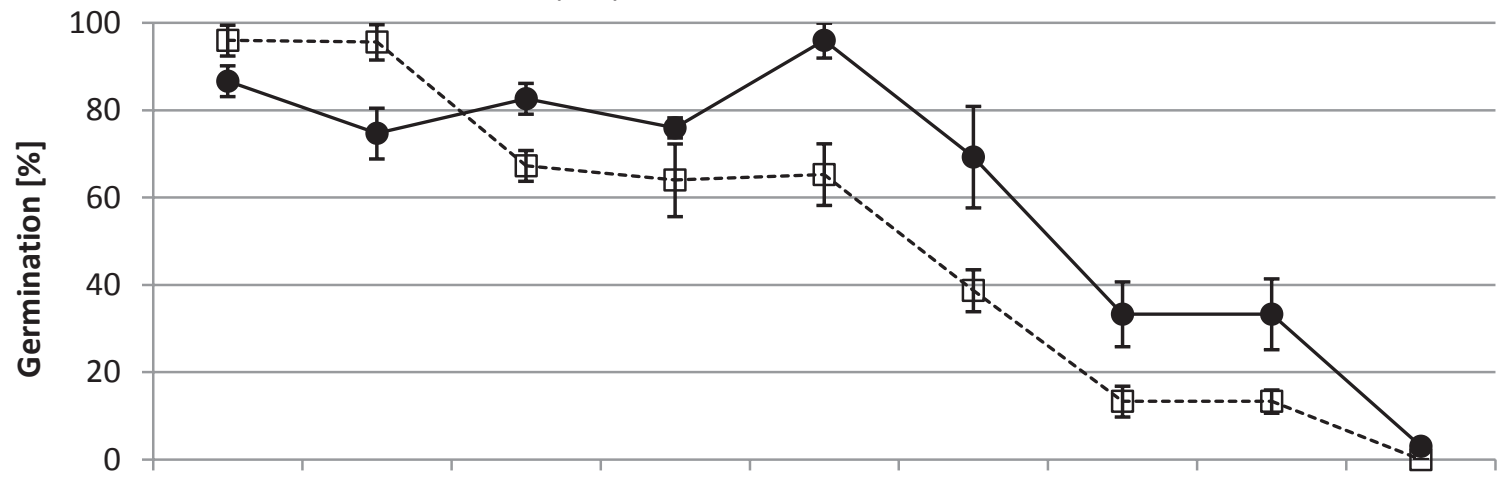

Nov 2004 Dec 2004 Jan 2005 Feb 2005 Mar 2005 Apr 2005 May 2005 Jun 2005 Apr 2006

[B]

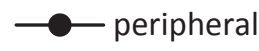

---@-- central

$26^{\circ} \mathrm{C}$

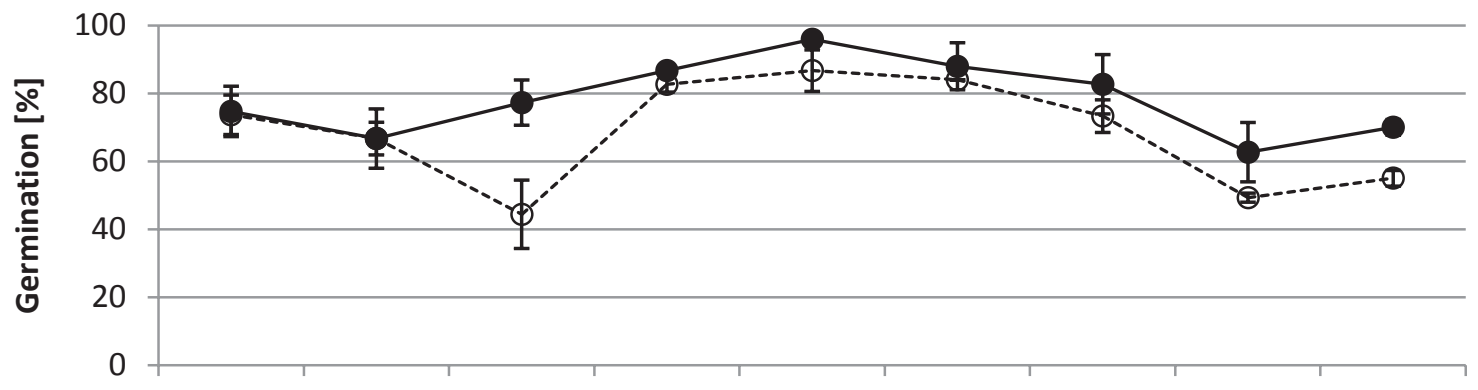

Nov 2004 Dec 2004 Jan 2005 Feb 2005 Mar 2005 Apr 2005 May 2005 Jun 2005 Apr 2006

[C]

$\longrightarrow$ peripheral

$---\odot--$ central

$34^{\circ} \mathrm{C}$

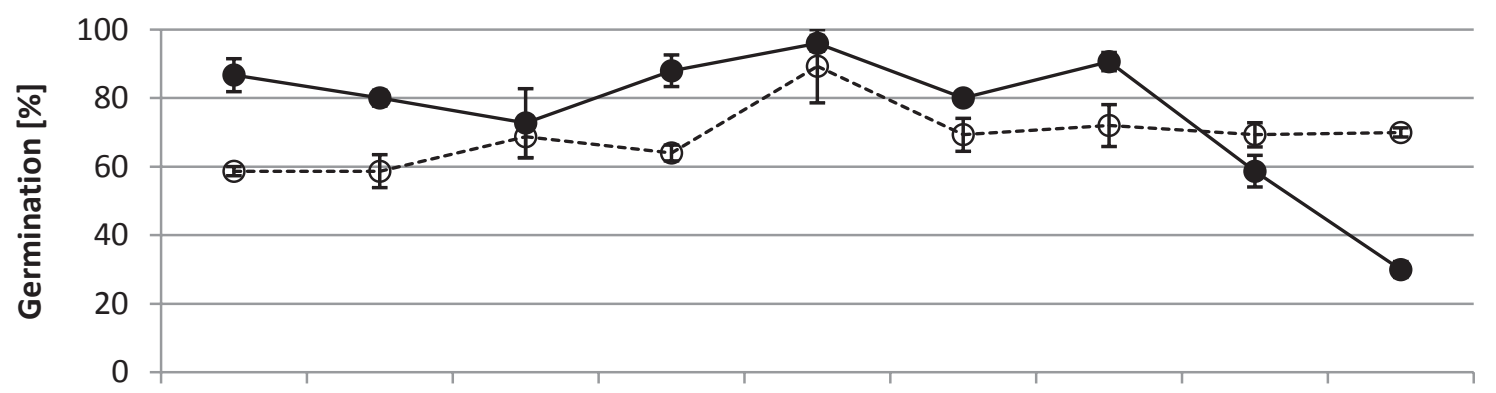

Nov 2004 Dec 2004 Jan 2005 Feb 2005 Mar 2005 Apr 2005 May 2005 Jun 2005 Apr 2006

Fig. 2. Germination percentage of dry stored (after 1-8 and 19 months) peripheral and central Galinsoga ciliata achenes. The achenes were tested at $12(\mathrm{~A}), 26(\mathrm{~B})$ and $34(\mathrm{C})^{\circ} \mathrm{C}$. Vertical bars indicate SE.

\section{Soil storage}

After becoming separated from the receptacle, G. ciliata achenes are deposited in the soil seed bank. After six and seven months of soil burial (exhumed in May and June), 90-95\% live achenes of both types were recovered (Table 1). Similar germination results were observed after six and seven months of soil storage. The germination capacity of dimorphic achenes was similar, reaching $89-99 \%$ at all temperature intervals
(Figs 3A, 3B). At $26^{\circ} \mathrm{C}$, the germination of both morph types was induced simultaneously on the second day (Fig. 5). Very high GR values were noted in respect of the peripheral achenes buried in soil for six months (exhumed in May, $26^{\circ} \mathrm{C}$ test) (Fig. 5). After 18 months of soil storage (successive growing season), the survival rates of both central and peripheral achenes were very low at $1-2 \%$ (Table 1 ). 


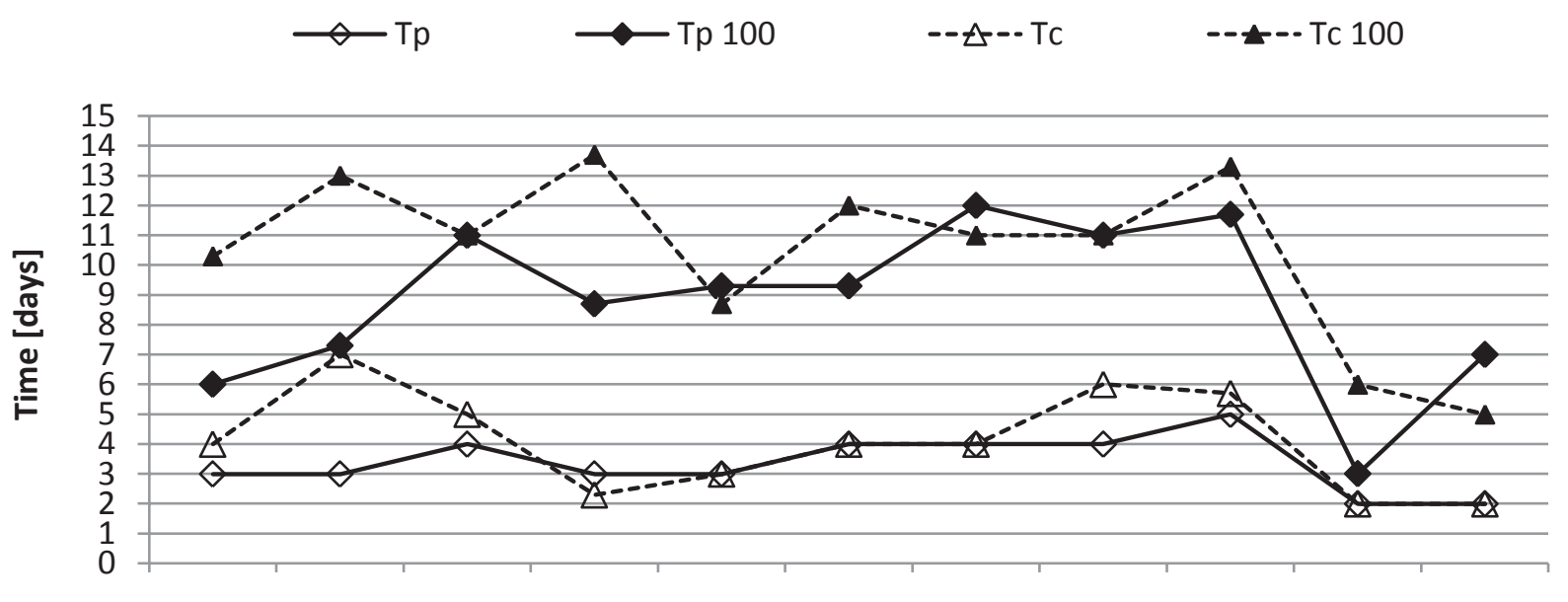

Nov 2004 Dec 2004 Jan 2005 Feb 2005 Mar 2005 Apr 2005 May 2005 Jun 2005 Apr 2006 May 2005 Jun 2005 exhumed exhumed

Fig. 3. Germination times [days] of heteromorphic Galinsoga ciliata achenes: T (time to first observed germinant; Tp - peripheral achenes, Tc - central achenes), T 100 (time to maximum germination; Tp 100 - peripheral achenes, Tc 100 - central achenes) stored dry (tested from Nov 2004 to Jun 2005 and in Apr 2006) and buried in the soil (exhumed in May 2005 and Jun 2005). The achenes were tested at $26^{\circ} \mathrm{C}$.

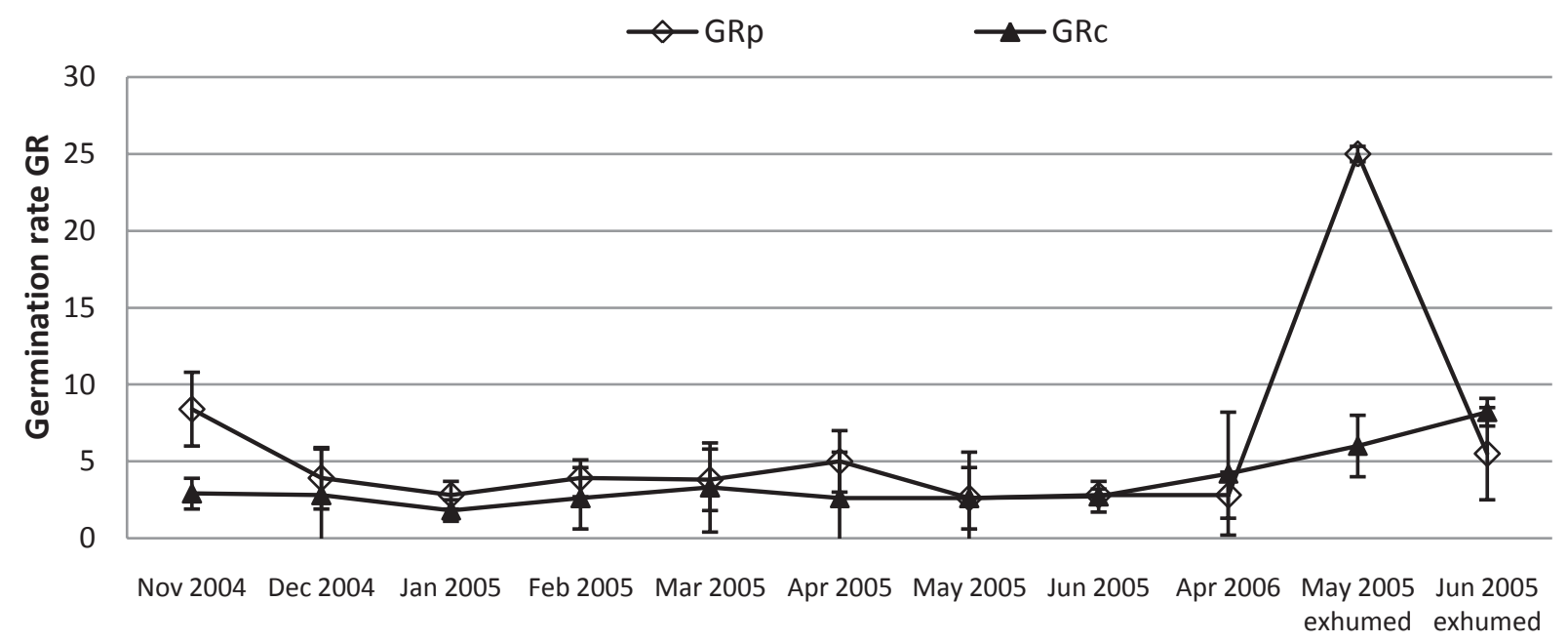

Fig. 4. Germination rate [GR] of heteromorphic Galinsoga ciliata achenes (GRp - peripheral achenes, GRc - central achenes) stored dry (tested from Nov 2004 to Jun 2005 and in Apr 2006) and buried in the soil (exhumed in May 2005 and Jun 2005). The achenes were tested at $26^{\circ} \mathrm{C}$. Vertical bars represent $\mathrm{SE}$.

Table 1.

Percentage $(\% \pm \mathrm{SE})$ of remaining firm achenes of Galinsoga ciliata buried in the soil.

The achenes were exhumed after 6, 7 and 18 months

(in May 2005, Jun 2005 and Apr 2006, respectively) after burial

\begin{tabular}{ccc} 
Times of burial [months] & Peripheral achenes & Central achenes \\
\hline 6 & $93 \pm 0,58$ & $95 \pm 1,00$ \\
7 & $90 \pm 1,15$ & $93 \pm 1,00$ \\
18 & $2 \pm 0,33$ & $1 \pm 0,33$ \\
\hline
\end{tabular}


[A]

6 months

$\square$ peripheral $\quad \square$ central

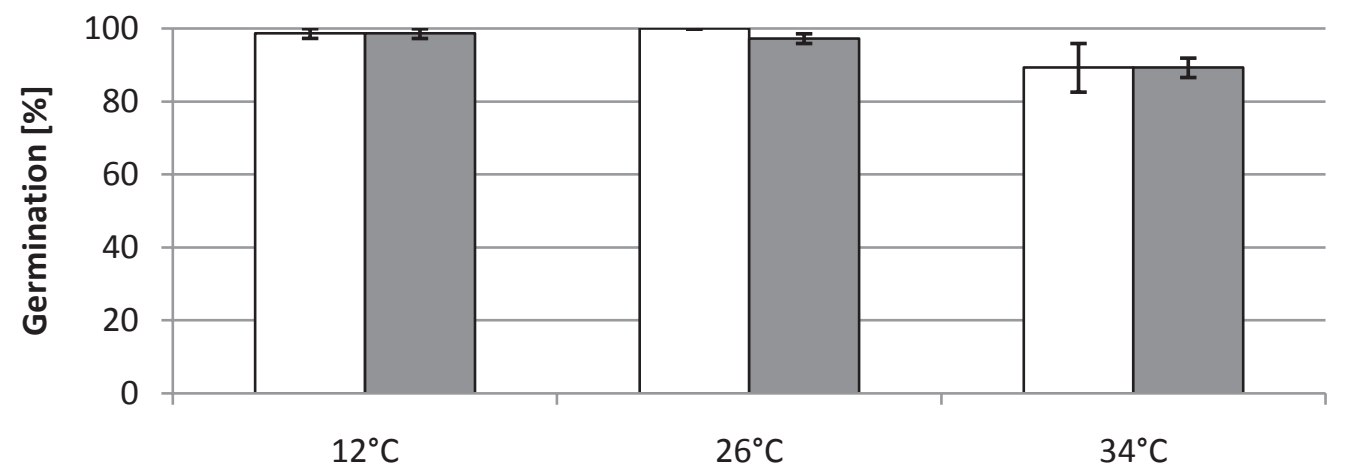

[B]

7 months

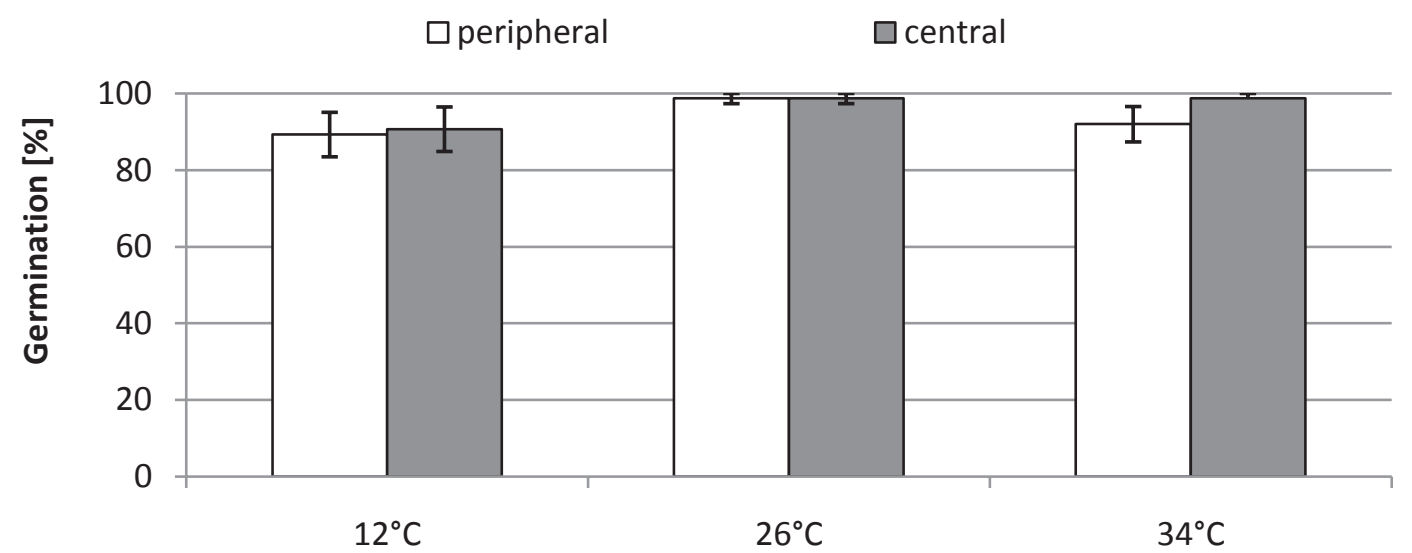

Fig. 5. Germination percentages of firm heteromorphic achenes of Galinsoga ciliata at 12, 26 and $34^{\circ} \mathrm{C}$ buried in the soil. The achenes were exhumed after six (May 2005) [A] and seven (Jun 2005) [B] months after burial. Vertical bars indicate SE

\section{DISCUSSION}

The observations of dimorphic G. ciliata achenes from the moment of separation from the maternal plant supported the determination which of the specific characteristics that developed in a tropical climate enabled the species to survive and settle in the local climatic zone. Directly after harvest (day one), the peripheral achenes of G. ciliata were dormant and showed no signs of germination, whereas the germination percentage of central achenes topped $60 \%$ at $26^{\circ} \mathrm{C}$ (Fig. 1). After one month of storage (late October), both achene types broke dormancy at 12,26 and $34^{\circ} \mathrm{C}$ (Fig. 2). It can be concluded that the fall emergence of the shaggy soldier in September (M. Kucewicz, personal observations) is initiated by peripheral achenes, while the germination of central achenes begins in the next month. The shaggy soldier is highly sensitive to low temperatures, and it is unable to survive the first signs of frost in a moderate climate (W e h s a rg, 1961). The above testifies to the species' origins in a subtropical climate where plants of the family Asteraceae produce non-dormant seeds (B a skin and B a skin, 1998). The species controls the timing of germination in non-dormant seeds by preventing germination until habitat temperatures increase or decrease enough to be within the range required for germination ( $\mathrm{B}$ a s ki n and $\mathrm{Ba}$ s k in , 1973). Observations of G. ciliata in East Bohemia were carried out by J u r s i k et al. (2003). The experiment did not differentiate between the achenes located in different parts of the capitulum, and the results were most probably limited to the more abundant central achenes. In the above study, achenes remained in deep dormancy from 10 to 100 days. According to the authors, the duration of primary dormancy was affected by the month and the year of harvest. The seeds exhumed in July and August were characterized by a longer primary dormancy period in comparison with the seeds harvested in September.

In the successive months of dry storage, the germination percentage of most peripheral achenes of G. ciliata was similar to or higher than the germination rate reported for central achenes (Fig. 2). Similar results were noted in G. parviflora, where ray achenes 
were characterized by higher germination percentage and rates in comparison with disc achenes. Testing temperatures and storage times were not specified in the referenced study (R a i and Tripathi, 1987).

The highest germination parameters were observed in the fifth month of storage (March), in particular as regards peripheral achenes which germinated at $96 \%$ at 12,26 and $34^{\circ} \mathrm{C}$, while the percentage of central achenes germinating at $34^{\circ} \mathrm{C}$ reached $89 \%$. A gradual decrease in the germination capacity of both achene types was noted in successive months of the experiment. In both achene types, germination rates deteriorated at a temperature of $12^{\circ} \mathrm{C}$. After 19 months of dry storage, the studied achenes failed to germinate at $12^{\circ} \mathrm{C}$. At a temperature of 26 and $34^{\circ} \mathrm{C}$, the same group of achenes continued to germinate at a relatively high level, and the germination percentages noted at $26^{\circ} \mathrm{C}$ reached $72 \%$ for peripheral achenes and $56 \%$ for central achenes, and at $34^{\circ} \mathrm{C}-70 \%$ for central achenes (Fig. 2). The effect of short-term and longterm storage on dormancy breaking was studied in a small number of heteromorphic species of the family Asteraceae (C o r kidi et al. 1991; E 1- K e b law y, 2003; Imbert, 1999; Rocha, 1996; Venable and Levin, 1985). The heteromorphic achenes of Bidens odorata were marked by higher germination percentage after seven and 16 months of dry storage than after 2 and 4 months (Corkidi et al. 1991). The optimal germination parameters in central achenes of Bidens pilosa were noted immediately after harvest, and their germination capacity decreased gradually in the successive months of storage $(6,9,14,20)$ ( $\mathrm{R} \mathrm{o}$ $\mathrm{c} h \mathrm{a}$, 1996). In Heterotheca latifolia, fresh central achenes germinated faster and in higher percentages than peripheral achenes, however peripheral achenes stored for two months germinated more rapidly and in higher percentages than when tested fresh $(\mathrm{V}$ e n a b le and Levin, 1985).

In north-eastern Poland, the emergence peak vital for the survival of the G. ciliata population is observed between May and June (M. Kucewicz, personal observations). Spring seedlings originate from the previous year's seed bank. The results of the experiment revealed that after six and seven months of soil storage, the studied achenes remained alive (Table 1) and yielded very high germination rates regardless of the morph type (Fig. 3). The central and peripheral achenes deposited in soil until the following season (18 months) did not survive and failed to form a permanent seed bank (Table 1). The behavior of dimorphic sexual propagules in the soil seed bank has seldom been explored. In a study investigating the related species of G. parviflora in Mexico, E s p in o s a-García et al. (2003) demonstrated that achenes formed a permanent seed bank and survived in soil for longer than two years. Dimorphic achenes differed with regard to their life span and the seed bank depletion rate. According to other researchers ( $\mathrm{Martine} \mathrm{z}$ Ghe rs a et al. 2000), G. parviflora formed transient seed banks. Varied survival and germination rates of dimorphic achenes in soil seed banks were also reported in Heterotheca latifolia (V e $\mathrm{n}$ able and L e v in, 1985). The multimorphic Heterosperma pinnatum did not create a permanent seed bank, and the depletion rate for the various achene types in the soil was quite comparable (V e n able et al. 1987).

The majority of G. ciliata diaspores did not survive the soil storage period of 18 months, and they did not form a permanent seed bank. When dry stored over the same period at $20^{\circ} \mathrm{C}$, they produced relatively a high germination percentage (Table 1, Fig. 1). Species creating aerial seed banks are characterized by non-dormant seeds that do not form permanent seed banks or require a short period of light exposure for germination (B a skin and Baskin, 1998). The results of observations suggest that $G$. ciliata is capable of creating aerial seed banks in tropical and subtropical climates. According to Martinez-Ghers a et al. (2000), the ability to form aerial seed banks probably compensates for the absence of a permanent soil seed bank.

\section{CONCLUSIONS}

1. In north-eastern Poland, Galinsoga ciliata achenes survived in soil only until the following growing season. $90-95 \%$ of both achene types remained alive after six and seven months of soil storage (exhumed in May and June). Dimorphic achenes were characterized by similar germination of $89-99 \%$ at all temperature intervals, and peripheral achenes harvested in May were the fastest to germinate.

2. The studied achenes did not form a permanent seed bank. After 18 months of storage in soil (successive growing season), most of the harvested achenes were dead.

3. Directly after harvest (day one), peripheral achenes remained dormant in the studied temperature ranges $\left(12,22,26^{\circ} \mathrm{C}\right)$. The germination of central achenes topped $60 \%$ at $26^{\circ} \mathrm{C}$, whereas no germination or very weak germination was noted at the remaining temperatures. Both achene types became non-dormant after one month of dry storage. In successive months of dry storage, peripheral achenes demonstrated a higher germination percentage than central achenes.

4. The peripheral and central achenes showed similar temperature requirements during dry storage. A similar germination pattern was observed in both achene types, with a germination peak in March (96\% of peripheral achenes germinated at 12, 26 and $34^{\circ} \mathrm{C} ; 90 \%$ of central achenes germinated at 26 and $34^{\circ} \mathrm{C}$ ). Germination capacity deteriorated 
over time. After 19 months of dry storage, both achene morphs failed to germinate at $12^{\circ} \mathrm{C}$. At a temperature of $26^{\circ} \mathrm{C}$ and $34^{\circ} \mathrm{C}$, the same group of achenes continued to germinate at a relatively high level (at $26^{\circ} \mathrm{C}$ : peripheral achenes $-72 \%$ and central achenes $-56 \%$; at $34^{\circ} \mathrm{C}$ - central achenes $-70 \%$ and peripheral achenes $-30 \%$ ).

5. After 19 months of dry storage at room temperature, diaspores were characterized by a high germination percentage, whereas most achenes failed to survive the same period of storage in soil. The above suggests that the species is capable of creating an aerial seed bank, a trait manifested in its center of origin.

\section{REFERENCES}

B askin J.M., B a sk in C.C., 1973. Ecological life cycle of Helenium amarum in central Tennessee. Bull. Torrey Bot. Club, 100: 117-124.

B a sk in C.C., B a sk in J.M., 1998. Seeds. Ecology, biogeography and evolution of dormancy and germination. Academic Press. San Diego.

Bouwmeester H.J., Karssen C.M., 1993. Annual changes in dormancy and germination in seeds of Sisymbrium officinale (L.) Scop. New Phytol. 124: 179-191.

Chmielewski J.G., 1999. Consequences of achene biomass, within-achene allocation patterns, and pappus on germination in ray and disc achenes of Aster umbellatus var. umbellatus (Asteraceae). Can. J. Bot. 77: 426-433.

Corkidi L., Rincon E., Vazquez-Yanes C., 1991. Effects of light and temperature on germination of heteromorphic achenes of Bidens odorata (Asteraceae). Can. J. Bot. 69: 574-579.

E1-Keblaw y A., 2003. Effects of achene dimorphism on dormancy and progeny traits in the two ephemerals $\mathrm{He}$ dypnois cretica and Crepis aspera (Asteraceae). Can. J. Bot. 81: 550-559.

E1lner S., Shmida A., 1984. Seed dispersal in relation to habitat in genus Picris (Compositae) in Mediterranean and arid regions. Isr. J. Bot. 33: 25-39.

Espinosa-García F.J., Vázquez-Bravo R., Martinez-R amos M., 2003. Survival, germinability and fungal colonization of dimorphic achenes of the annual weed Galinsoga parviflora buried in the soil. Weed Res. 43: 269-275.

Harper J.L., 1977. Population biology of plants. Academic Press. New York.

Imbert E., 1999. The effects of achene dimorphism on dispersal in time in Crepis sancta (Asteraceae). Can. J. Bot. 77: 508-513.

I m ber t E ., 2002. Ecological consequences and ontogeny of seed heteromorphism. Perspect. Plant Ecol., Evol. Syst. 5: $13-36$

Jursík M., Soukup J., Venclová, Holec J., 2003. Seed dormancy and germination of Shaggy soldier ( $\mathrm{Ga}$ linsoga ciliata Blake.) and Common lambsquarter (Chenopodium album L.). Plant Soil Environ. 49: 511-518.
Korniak T., 1997. Współczesne przemiany flory segetalnej w północno-wschodniej Polsce. / Current changes in segetal flora in north-eastern Poland. Ogólnopolska Konferencja Naukowa. Doskonalenie Technologii Produkcji Roślin Warzywnych. XVI Spotkanie Zespołu Herbologicznego Komitetu Nauk Ogrodniczych PAN. Olsztyn 24-25 czerwca 1997: 1-9 (in Polish).

Kulpa W., 1988. Nasionoznawstwo chwastów. Państwowe Wydawnictwo Rolnicze i Leśne, Warszawa (in Polish).

Majdecka-Zdziarska E., 1929. Żółtlica drobnokwiatowa i żółtlica owłosiona - Galinsoga parviflora Cav. et Galinsoga hispida Benth. Bulletin International de l'Académie Polonaise des Sciences et des Letters №1B1, Imprimerie de l'Université, Cracovie: 105-139.

Martinez-Ghersa M.A., Ghersa C.M., BenechArnold R.L., Mac Donough R., Sanchez R.A., 2000. Adaptive traits regulating dormancy and germination of invasive species. Plant Spec. Biol. 15: $127-137$.

Matilla A., Gallardo M., Puga-Hermida M.I., 2005. Structural, physiological and molecular aspects of heterogeneity in seeds: a review. Seed Sci. Res. 15: 63-76.

Rai J.P.N., Tripathi R.S., 1987. Germination and plant survival and growth of Galinsoga parviflora Cav. as related to food and energy content of its ray- and disc-achenes. Acta Oecol. 8: 155-165.

Rocha O.J., 1996. The effects of achene heteromorphism on the dispersal capacity of Bidens pilosa L. Int. J. Plant Sci., 157: 316-322.

Rosselló J.A., Mayol M., 2002. Seed germinaton and reproductive features of Lysimachia minoricensis (Primulaceae), a wild-extinct plant. Ann Bot. 89: 559-562.

Symonides E., 1989. Bank nasion jako element strategii reprodukcyjnej terofitów./ Seed bank as an element of annual reproduction strategy. Wiad. Ekol. 35: 107-144 (in Polish with English summary).

Venable D.L., 1985. The evolutionary ecology of seed heteromorphism. Am. Nat. 126: 577-595.

Venable D.L., Burquez A., Corral G., Morales E., Espinosa F., 1987. The ecology of seed heteromorphism in Heterosperma pinnatum in central Mexico. Ecology, 68: 65-76.

Venable D.L., Dyreson E., Morales E., 1995. Population dynamic consequences and evolution of seed traits of Heterosperma pinnatum (Asteraceae). Am. J. Bot. 82: 410-420.

Venable D.L., Lawlor L., 1980. Delayed germination and dispersal in desert annuals: escape in space and time. Oecologia, 46: 272-282.

Venable D.L., Levin D.A., 1985. Ecology of achene dimorphism in Heterotheca latifolia. I. Achene structure, germination and dispersal. J. Ecol. 73: 133-145.

Wehsarg O., 1961. Chwasty polne. Państwowe Wydawnictwo Rolnicze i Leśne (in Polish). www.iop.krakow. $\mathrm{pl} / \mathrm{ias} / 2010$ 


\section{Wpływ heteromorfizmu na kiełkowanie niełupek żóltlicy owłosionej [Galinsoga ciliata (Rafin) S.F. Blake]}

\author{
Streszczenie
}

Żółtlica owłosiona (Galinsoga ciliata) wytwarza w kwiatostanie niełupki brzeżne i środkowe. Celem badań było: 1) zbadanie wpływu czasu przechowywania w warunkach suchych na kiełkowanie oraz 2) zbadanie wpływu przechowywania w glebowym banku nasion na przeżywalność i kiełkowanie heteromorficznych diaspor. Bezpośrednio po zbiorze peryferyczne niełupki znajdowały się $\mathrm{w}$ spoczynku, niełupki środkowe kiełkowały w 60\%. Po 1 miesiącu suchego przechowywania oba typy niełupek stawały się niespoczynkowe. W trakcie kolejnych miesięcy niełupki brzeżne zwykle kiełkowały lepiej niż środkowe. Wymagania temperaturowe brzeżnych i centralnych nielupek $\mathrm{w}$ trakcie przechowywania w tych warunkach były na zbliżonym poziomie. Obserwowano podobny wzorzec kiełkowania peryferyjnych i środkowych niełupek z maksimum kiełkowania w marcu (brzeżne w 12,26 i $34^{\circ} \mathrm{C}$ kiełkowały w $96 \%$; centralne w temp. 26 i $\left.34^{\circ} \mathrm{C}-90 \%\right)$. W późniejszym okresie zdolność kiełkowania obniżała się. Po 19 miesiącach niełupki obu typów $\mathrm{w} 12^{\circ} \mathrm{C}$ nie kiełkowały, natomiast w 26 i $34^{\circ} \mathrm{C}$ kiełkowanie wciąż było wysokie (w $26^{\circ} \mathrm{C}-$ brzeżne $-70 \%$ i środkowe $-58 \%$; w $34^{\circ} \mathrm{C}$ - środkowe $-70 \%$, brzeżne $-30 \%$ ).

Po 6 i 7 miesiącach w glebie (wykopane w maju i w czerwcu) atrybuty przeżycia utrzymywało $90-95 \%$ niełupek każdego rodzaju. Dymorficzne niełupki kiełkowały we wszystkich zastosowanych temperaturach na zbliżonym poziomie (89-99\%), ale najszybciej z nich kiełkowały niełupki peryferyjne wykopywane w maju. Po 18 miesiącach w glebie (kolejny okres wegetacyjny) większość niełupek była martwa. Niełupki nie tworzyły trwałego banku nasion. 